\title{
QUAL NATUREZA HUMANA? QUE APERFEIÇOAMENTO? QUAL FUTURO? REFLEXÕES EM TORNO DO CONCEITO DE NATUREZA HUMANA AMPLIADA
}

\author{
WHICH HUMAN NATURE? WHAT ENHANCEMENT? WHAT FUTURE? \\ REFLECTIONS AROUND THE CONCEPT OF HUMAN NATURE EXTENDED
}

\author{
MURILO MARIANO VILAÇA \\ (UFRJ / Brasil)
}

\begin{abstract}
RESUMO
Um modo de aperfeiçoamento humano desponta, atualmente, como inovador e problemático: o bioaperfeiçoamento. Concebendo o humano como um ser fundamentalmente biológico e o seu aperfeiçoamento como uma matéria basicamente biotecnocientífica, esta modalidade de melhoramento causa sentimentos opostos. Inobstante opostos, o medo e a esperança referem-se, grosso modo, a um mesmo ponto: a alteração da natureza humana. Este artigo analisa o conceito de natureza humana, a fim de mostrar como uma acepção ampliada oferece ganhos teóricoconceituais, permitindo outra visada sobre pontos fundamentais desse tema central em ética aplicada.
\end{abstract}

Palavras-chave: Natureza humana ampliada; Aperfeiçoamento humano; Biotecnociência; Pós-humanidade

\begin{abstract}
One way to human enhancement emerges as innovative and problematic: the bio-enhancement. Conceiving the human being as a fundamentally biological and its enhancement as a matter biotechnoscientific basically, this type of improvement because opposing feelings and stance. Although opposite, fear and hope refers in general to the same point: the change of human nature. This article examines the concept of human nature in order to show how a larger sense offers theoretical and conceptual gains, allowing another target key points about this central issue in applied ethics.
\end{abstract}

Keywords: Expanded Human Nature; Human Enhancement; Biotechnoscience; Posthumanity

\section{Posicionando o problema: era biotecnológica e o humano melhor}

"Pela primeira vez Deus tem um rival" (Jean-Pierre Dupuy)

Dupuy (2008) enceta sua reflexão mencionando a frase acima, dizendo que ela foi usada pelo grupo ETC, um lobby ambientalista, para saudar, ironicamente, o anúncio do J. Craig Venter 
Institute. O alvo da crítica era a prematura divulgação da capacidade de sintetizar DNA artificialmente, que é uma tecnologia bastante aguardada, e também temida, nos últimos tempos. A fabricação de vida é o ovo de Colombo da biologia sintética, ramo científico cujos poderes assombram para o bem e para o mal (RABINOW e BENNETT, 2012). Formas de vida estão, ao que parece, próximas de serem criadas em laboratório. Mas, antes de criamos novos organismos vivos, há outra possibilidade biotecnocientífica que desperta questionamentos sobre a usurpação de funções tidas como divinas ou da natureza, a saber, o aperfeiçoamento humano.

O humano pode ser melhorado? Podemos criar vidas humanas melhores? Há apenas uma forma de fazê-lo? Se considerarmos que o aperfeiçoamento humano reúne um sem-número de investimentos humanos através de atividades, procedimentos, técnicas, práticas diversos e milenares, pode-se responder às duas primeiras questões que sim ou, ao menos, que o Homem tem apostado em tal possibilidade perenemente; e, à segunda, que não, vez que há uma multiplicidade de meios tidos como aperfeiçoadores. Os humanos, então, estariam familiarizados com a ideia e com a criação de meios para promovê-la, de modo que falar em aperfeiçoamento não deveria causar alarde, temores, exasperações.

Historicamente, os humanos investem em variadas práticas ou técnicas tidas como aperfeiçoadoras: ler livros ou apreciar manifestações artísticas e culturais; educação formal e informal; adoção de certa dieta, consumindo alimentos que fariam bem à saúde ou promoveriam alterações fenotípicas tidas como benéficas; prática de exercícios físicos são alguns exemplos. É difícil afirmar categoricamente que tais práticas sejam destituídas de dilemas normativos. Mas, conquanto haja problemas morais e políticos em torno dos procedimentos educativos, nutricionais, estéticos, de saúde pública, etc. adotados em dada sociedade, eles não são alvo de questionamento normativo, por assim dizer, amplamente restritivos, sendo, em alguma medida, aceitos como legítimos, necessários e benéficos (DIAS e VILAÇA, 2010; ALLHOFF et al., 2010).

No entanto, outras iniciativas pró-melhoramento não gozam da mesma aceitação, enfrentando mais e severas objeções. O grupo mais problemático, se se puder chamar assim, diz respeito, notadamente, às tecnologias de aperfeiçoamento humano que se distinguem da mera terapia, distinção endossada, sobretudo, pelos que assumem uma posição anti-aperfeiçoamento, os chamados bioconservadores (KASS, 2003; HABERMAS, 2004; COLE-TURNER, 2011). A fim de melhorar nossos corpos, mentes, habilidades, capacidades, incrementando o nosso bem- 
estar, estendendo a manipulação da natureza humana para o campo da alteração de algumas capacidades humanas para mais, perspectiva-se a criação de indivíduos com uma gama de funcionamentos que se distinguem do que é chamado de normalidade (ALLHOFF et al., 2010). O Human Plus ('humano mais'), um humano diferenciado dos 'humanos normais', seria o objetivo. Este, por sua vez, seria alcançável pela implementação de um vasto matiz de biotecnologias, o que tem despertado reações distintas.

O anúncio de que uma Era biotecnológica se aproxima é endossado por vários autores de diferentes vertentes (FUKUYAMA, 2002; LECOURT, 2003; BOSTROM, 2005 e 2009; JOTTERAND, 2010). Há um relevante consenso de que a humanidade, há muito marcada pelas intervenções científicas e técnicas, será ainda mais profunda e radicalmente afetada futuramente por um tipo bem específico de intervenção humana, a saber, a biotecnocientífica e biotecnológica (LECOURT, 2003). Isto leva, por exemplo, Perssons e Savulescu (2011) a falarem em bioaperfeiçoamento, Buchanan (2011b) a se referir ao aperfeiçoamento biomédico e Cole-Turner (2011) a um aperfeiçoamento tecnológico. Há previsão da tangibilidade de um radical biodesign, isto é, a ideia de que, para além da terapia, o humano poderá, em um nível superior ao que já faz, planejar meticulosamente a sua vida e da sua descendência, e até mesmo criar vida (VILAÇA e PALMA, 2011; RABINOW e BENNETT, 2012).

É fato que as biociências, há muito, configuram a vida de uma parcela bastante considerável de humanos. Fármacos, implementos nutricionais e vitamínicos, intervenções cirúrgicas terapêuticas e estéticas, técnicas reprodutivas, etc. dão formas variadas às vidas dos homens e mulheres faz tempo. Contudo, para muitos, os recentes avanços da biotecnociência, especialmente no campo da nova genética e da biologia sintética, instituem inovações e permitem excogitar possibilidades de intervenção sem precedentes na história, devendo ser destacados face aos poderes que lhe são reportados.

Muitas e antagônicas são as expectativas e os sentimentos envolvidos. A possibilidade do aperfeiçoamento, melhoramento ou aprimoramento humano é uma delas, talvez a mais aguardada e, concomitantemente, temida. Pode-se dizer que o que está em questão é um novo grau de alteração e determinação da biologia humana. Hipoteticamente beneficente ou maleficente, crê-se que o humano estará, desde a sua origem (dos genes), à disposição do planejamento, da artificialização, da seleção racional e tecnocientífica. Nos termos de Agamben (2002), alterar-se- 
á a zoé para a modificar o bios. Há, neste sentido, uma aposta na ideia de que mudando a natureza humana poderemos alterar os modos de vida social, política e moral da espécie.

Isto nos leva ao segundo destaque: a criação de uma nova espécie de ser vivo. Para muitos autores, até mesmo de opostos pontos de vista, a ideia de que ingressaremos em um futuro póshumano é tangível e iminente. Savulescu (2009) prevê que, em um futuro cenário de desenvolvimento biotecnológico, aquele que será instaurado com o progresso tecnológico no século XXI, o novo dilema moral central emergirá. Ao invés de enfrentarmos a questão de que atitudes e deveres morais temos para com os seres que são compreendidos, atualmente, como animais não-humanos (por exemplo, gato, cachorro, cavalo, etc.), a questão será que obrigações teremos com outro tipo de não-humano, os chamados pós-humanos.

A suposição de que a natureza humana será radicalmente alterada e que isso gerará uma nova espécie tem produzido, grosso modo, uma reação de cunho maniqueísta, o que situa a biotecnociência entre o temor e a esperança exacerbados, entre o 'mal' e o 'bem' radicais. Dentre outras discordâncias, enquanto uns defendem que a condição pós-humana será o resultado mais promissor do real poder beneficente da biotecnociência, pois ela representaria o ápice do aperfeiçoamento humano; outros temem que o seu eventual poder maleficente comprometa radical e incontornavelmente a natureza humana e tudo que, tradicionalmente, tem sido fundamentado nela (automia, liberdade, autenticidade, etc.). Assim, o espectro pós-humano, de um lado, e a esperança pós-humana, de outro, polarizam grosseiramente o debate em torno do bioaperfeiçoamento, dilema que contesto na última seção deste artigo.

Em suma, é a ideia do aperfeiçoamento humano de cunho fundamentalmente biológico e por meios exclusivantemente biotecnocientíficos que analiso ao longo deste texto. Meu objetivo é questionar acepções de natureza humana tradicionais, propondo o conceito de natureza humana ampliada, concebida como fundamentalmente biológica, multifacetada, processual e mutável. A partir dele, refuto a tese da pós-humanidade, a fim de desqualificá-la como um ponto central do debate em torno do aperfeiçoamento humano.

\section{Tudo que é natural é divino e bom? Contestação de uma tradição}

Embora, ou justamente porque, o meu entendimento acerca do apelo a algo como uma natureza humana seja um dos equívocos centrais do debate sobre o aperfeiçoamento humano, um 
exame de tal conceito é imprescindível. Indubitavelmente, o que Dias e Vilaça (2010) denominam de argumento da natureza humana é uma das marcas do debate, o qual é evocado especialmente pelos chamados bioconservadores (FUKUYAMA, 2002; KASS, 2002 e 2003; HABERMAS, 2004; SANDEL, 2007). De certa forma, isso obriga os que defendem o aperfeiçoamento humano, notadamente os chamados transumanistas, a lidar com esse obscuro conceito, a fim de retorquir uma das bases dos seus críticos. Antes, porém, de apresentar os meus argumentos sobre esse conceito, quero contestar a ideia de que tudo que é natural é bom ou deve ser preservado.

O conceito de natureza, sentido amplo, é um dos clássicos problemas filosóficos. Os chamados pensadores originários já buscavam estabelecer em que consistia a realidade da physis, quais suas leis, seus elementos e relações essenciais (BACKES et al., 2010). Em geral, a tradição consagrou a compreensão de que referir-se à natureza de uma coisa é voltar-se para sua essência, aquilo que a constitui, suas características básicas, seus funcionamentos - para alguns, entendidos como coisas imutáveis (BACKES et al., 2010) -, estabelecendo, por fim, algum grau de previsibilidade quanto à sua estrutura e ao seu comportamento.

De acordo com Merleau-Ponty (2006), em Aristóteles, temos a idéia de que pensar a natureza (das coisas) é refletir sobre uma orientação para um tipo, uma ordem, um destino necessários. Ele formula uma teoria de natureza que vincula as coisas a um destino qualitativo, uma teoria causas-fins referente a um mundo qualitativamente dividido em regiões. Por exemplo, os corpos leves sobem, pois é de sua natureza ir para o alto, assim como os pesados, por natureza ligados à terra, caem.

O racionalismo filosófico moderno também toma a natureza como objeto de investigação. A ideia de que a natureza (ou Deus) possui algumas qualidades geralmente atribuídas aos humanos foi endossada de alguma forma até mesmo por pensadores modernos, como, dentre tantos outros, são os casos de Adam Smith e Kant. No caso do filósofo e economista escocês, vêse, por exemplo, na obra Teoria dos Sentimentos Morais, a função central do conceito de natureza - ora com "n", ora com "N" - para a argumentação desenvolvida. Smith (2002) chega a afirmar coisas como que a natureza exorta os homens a atos de beneficência (p. 107); que plantou no peito humano a consciência do mau merecimento (p. 108); ou que pela sabedoria da natureza, a felicidade do homem inocente é preservada (p. 133), entre outras dezenas de passagens em que a $(\mathrm{N})$ natureza é evocada. Além disso, há uma clara ligação entre o conceito de 
natureza utilizado e a ideia de Deus, embora haja controvérsias entre os comentadores. Numa passagem relativamente extensa que, por esse motivo, não reproduzirei aqui na íntegra, Smith defende que os princípios naturais, os quais uma “(...) refinada e esclarecida razão teria nos recomendado (...)" (2002, p. 109), não devem ser imputados à sabedoria humana, mas sim à divina.

No caso do filósofo alemão, a obra Ideia de uma história universal de um ponto de vista cosmopolita exemplifica outro recurso à natureza como possuindo uma intencionalidade. Kant (2010) afirma, sob o conhecido conceito da insociável sociabilidade, que enquanto os homens buscam seus próprios interesses, inclusive fazendo guerras, a natureza os guia para a sua finalidade. Ou seja, nada foge aos propósitos enigmáticos da natureza.

Outro sentido bastante comum é que a natureza deve ser preservada, porque ela é o que poderia ser chamado de benfazeja. Crê-se que tudo está sob seu controle, inclusive que ela pune o Homem pela sua tolice. Acredita-se, também, que há um propósito para tudo que ela faz e que a sua intervenção tende a (re)estabelecer uma harmonia ideal ou primitiva. Mexer na natureza é, com isso, um ato de imprudência, algo temerário ou, mesmo, maléfico. A catástrofe, a extinção, o fim dos tempos, o mal radical estão, de dado ponto de vista, sempre à porta de quem 'desrespeita' a natureza. O Homem, mal, inconsequente, ganancioso, etc.; a natureza, boa, sábia, prudente, necessária, etc. são considerados como antípodas de um mesmo mundo.

A impertinência dessa visão desponta desde o tácito pressuposto de que há o humano e a natureza, isto é, que ambos não se confundem de alguma forma, como que formando conjunto e subconjunto. Além disso, cabe objetar, se a natureza (ou Deus) tudo fez, o Homem é sua criação. Assim, se o humano possui traços negativos, isso deve recair sobre a natureza.

McKibben (2003), conhecido ambientalista norte-americano, é um exemplo dessa perspectiva positiva de natureza, a qual pode ser chamada de muitas formas: biocatastrofista, tecnofóbica, luddista, conservacionista, etc. Conquanto não seja alvo de uma análise acurada aqui, o interessante debate sobre a preservação do meio-ambiente - claramente dominado pelos que, do lado do 'bem', defendem a central responsabilidade humana acerca das nefastas mudanças climáticas - tem sido paulatinamente mudado com o crescimento em número e força das posturas contrárias às teses do aquecimento global como uma consequência direta e exclusiva da ação humana deletéria. 
Sem saber se uma acusação ideológico-econômica seria a melhor ou suficiente forma de refutá-las, o fato é que estudiosos (ambientalistas, geógrafos, físicos, etc.) têm utilizado dados históricos para fundamentar a tese de que houve, na natureza, por motivos desconhecidos, alterações que inviabilizaram certas formas de vida na Terra em momentos em que os humanos sequer existiam. Assim, a natureza pode, periodicamente, provocar mudanças radicais, as quais são tidas como más.

Duvidando de um veredicto final sobre 'quem tem a culpa' exclusiva, excogitando que uma saída plausível é a opção pelo meio-termo, pela responsabilidade compartilhada, a proteção do que é natural me parece ideologicamente comprometida com a ideia de que ela é sempre boa.

A crítica de Bostrom e Sandberg (2009), que confirma a existência dessa tendência unilateral, é interessante. Apesar de ser mais ou menos difundida a ideia de que é mais seguro ou é melhor usar remédios 'naturais', consumir comida 'natural' ou suplementos 'naturais' como formas 'seguras' de melhorar as capacidades humanas, a crença na sabedoria da natureza é parcialmente verdadeira. Partindo da Evolutionary Medicine (medicina evolutiva), que corresponde a um campo de pesquisas interdisciplinar, eles questionam por que a natureza, no processo de evolução, reteve alguns traços ou genes que desencadeiam doenças e outras coisas tidas como males, e não outros que não os causam.

Essa pergunta permite questionar: se dada técnica ou intervenção produz bons efeitos, ou seja, servirá para contornar males, por que a natureza, ela mesma, não os produziu? Por que a natureza não protagoniza todos os passos do desafiador processo de evolução otimizadora? Decerto, alguém poderia retorquir, à moda kantiana, afirmando que há alguma intenção profunda e misteriosa, mas plausível para isso, e que não cabe ao humano contestar os desígnios ininteligíveis da natureza com a sua racionalidade limitada, inconsequente e malévola. Mas, poder-se-ia contra-arrazoar, a capacidade humana de se automodificar não seria fruto da evolução capitaneada pela natureza, de modo que entraríamos num beco sem saída, tendo de combater algo natural? Ou seja, se tudo que somos, incluindo a razão, é resultado daquilo que a natureza sabiamente fez, tal capacidade seria naturalmente boa e necessária, e seus efeitos seriam positivos, desejáveis, etc. Talvez, como defendo ao longo deste artigo, nenhuma forma de maniqueísmo seja a mais adequada de pensar a relação entre natureza e humano.

Buchanan (2011a) também contesta a radical benignidade e sabedoria da natureza citando Darwin, para o qual a natureza é sangrenta e inepta. Contudo, parece-me que a atribuição de 
qualquer característica desse tipo, quer positiva, quer negativa, é inadequada. A minha perspectiva é que a nada inumano deve ser atribuído racionalidade, intencionalidade ou sabedoria, tampouco os seus antônimos.

Contrariando as tendências citadas, penso que a antropomorfização de entidades nãohumanas pode representar uma forma de o humano se eximir de pôr em ato a capacidade de se transformar, alterando parcialmente a sua condição, com vistas ao que ele entende como benéfico em dado momento histórico, e, sobretudo, de arcar com responsabilidade por isso. Como uma tentativa de saída - ou permanência na menoridade -, o homem cria uma espécie de fetiche que lhe ajuda a conviver com a covardia diante da sua natureza demiúrgica.

Recorro ao materialista Holbach (2010) para expressar mais claramente a minha ideia:

\begin{abstract}
Um ser inteligente é um ser que pensa, que quer, que age para alcançar um fim. Ora, para pensar, para querer, para agir à nossa maneira é necessário ter órgãos e objetivo semelhantes aos nossos. Assim, dizer que a natureza é governada por uma inteligência é pretender que ela é governada por um ser provido de órgãos, já que sem órgãos não pode haver percepção, nem ideia, nem intuição, nem pensamento, nem vontade, nem ação (p. 100; grifo no original).
\end{abstract}

O receio humano de agir e se responsabilizar motivaria, nesse sentido, a admissão de ficções às quais se atribui propriedades humanas e sobre as quais é depositada a tutoria da vida humana, da existência, bem como do seu melhoramento, transferindo prerrogativas e responsabilidades.

Analogamente ao que Kant defende na resposta ao que é o Esclarecimento, parece-me que o humano preserva - por medo, preguiça ou conveniência - uma postura tutorada, recusando-se a, corajosamente, assumir suas responsabilidades quanto ao seu futuro. No que tange à sua biologia ou natureza, alguns humanos optariam por se manter numa menoridade, submetendo-se à tutoria da natureza, de Deus ou entidades afins, correndo o sério risco de elas simplesmente inexistirem ou não terem intencionalidade. Tais indivíduos apostam que 'elas sabem o que fazem', que nos guiam na retidão de seus desígnios misteriosos, mas sábios, posto que garantissem a boa ordem de tudo que há. E mais, até aonde ocorrem, do ponto de vista humano, tolices, desarmonias e erros, estes são tidos como apenas aparentes, visto que, no fundo, houvesse alguma intenção correta. Em certo sentido, é a presença da ideia de que 'deus (ou a natureza) escreve certo por linhas tortas'.

Uma constatação que seduz a acreditar haver uma inteligência inumana são as chamadas leis ou princípios da natureza, os quais estabelecem algum ordenamento e regularidade basilares. ethic@-Florianópolis v.12, n. 1, p.25-51, Jun. 2013. 
No entanto, não está claro por que do fato de haver leis relativamente constantes e universais na natureza, as quais ajudam a compreender parcialmente o movimento metamorfoseático da natureza, deve-se inferir que haja alguém, uma intenção inteligente por detrás disso. Por que não antes o nada do que uma Razão? Ou, então, por que diante de um mistério não nos calamos em vez de conjecturar explicações mirabolantes sobre as causas primeiras, dedicando-nos, humildemente, a compreender o que é possível no momento? A falta de uma explicação para um fenômeno ou a refutação de uma que até então satisfazia a curiosidade humana não o torna algo divino, milagroso ou coisa semelhante, mas apenas algo inexplicável.

Sobre isso, recorro à perspectiva materialista de Holbach (2010):

\begin{abstract}
Aquilo que nós chamamos de prodígios, de maravilhas, de efeitos sobrenaturais, são fenômenos da natureza dos quais nossa ignorância não conhece os princípios nem a maneira de agir e que - na falta de conhecer as suas causas verdadeiras - atribuímos loucamente a causas fictícias que, assim como a ideia de ordem, só existem em nós mesmos, à medida que as colocamos fora de uma natureza para além da qual nada pode existir (p. 94; grifos no original).
\end{abstract}

Disso decorre, assim penso, que, quanto ao aperfeiçoamento biológico humano, não precisamos nos preocupar com os insondáveis desígnios divinos ou da Natureza, mas tão somente com as leis e princípios da natureza (neste caso, os biológicos), seu ordenamento intricado com fatores externos, sobre os quais interviremos. São eles, por mais complexos e incompreensíveis na sua totalidade que sejam, que têm de ser desvendados, compreendidos e explicados cuidadosamente, o que tornam as ciências da natureza (no caso, as biociências) algo precioso, ainda que não todo-poderosas. Penso que a ideia de aperfeiçoamento da natureza humana deve seguir a trilha das explicações imanentes, pois elas ajudam a compreender mais claramente quanto possível as pretensões da biotecnociência.

Enfim, a natureza não é sábia, nem tola; racional ou irracional; boa ou má, pois toda essa nomenclatura é uma forma humana de emitir seus juízos sobre o que lhe é desejável ou indesejável, bem como sobre aquilo com o qual estamos familiarizados. Quer dizer, ela é tida como boa se satisfaz ou promove as humanas expectativas, preferências, vontades, etc.; é má, se lhas compromete.

Embora seja legítimo emitir juízos de valor sobre a natureza, o problema reside em naturalizá-los ou essencializá-los, pois isso cria uma atmosfera argumentativa baseada em neutralidade, ensejando, até mesmo, falácias naturalistas. Para mim, quando creditamos à natureza algo bom ou mau não estamos nos referindo a algo em si. Ao invés, estamos ethic@- Florianópolis v. 12, n. 1, p.25-51, Jun. 2013. 
interpretando de acordo com certas concepções de bem ou relações de familiaridade. No caso do tema analisado, referir-se a uma natureza humana e ao seu aperfeiçoamento também é prenhe de juízos de valor. Há uma escamoteada opção por selecionar apenas algumas características que definiriam a natureza humana 'normal'. Semelhantemente, arbitra-se sobre o que é tornar o humano melhor. Geralmente, entende-se que melhorar o humano é retirar o que compromete a visão restrita de natureza humana adotada, seguida da elevação da performance das características selecionadas para defini-la.

A abordagem de Holbach (2010) das noções de ordem e desordem é análoga ao que acabo de afirmar, na medida em que coisas indesejáveis (por exemplo, patologias) são tidas, por vezes, como desordens orgânicas:

a ordem e a desordem da natureza não existem. Nós encontramos a ordem em tudo aquilo que está em conformidade com o nosso ser e a desordem em tudo aquilo que lhe é oposto. Entretanto, tudo está em ordem em uma natureza da qual nenhuma das partes pode jamais se afastar das regras certas e necessárias que decorrem da essência que elas receberam. Não existe nenhuma desordem em um todo para a manutenção do qual a desordem é necessária, cuja marcha geral não pode jamais ser desordenada, onde todos os efeitos são consequências de causas naturais que agem como devem infalivelmente (p. 93-4).

Ele segue afirmando que:

a ordem e a desordem nada mais são que palavras pelas quais nós designamos estados nos quais
os seres particulares se encontram. Um ser está em ordem quando todos os seus movimentos
conspiram para a manutenção de sua existência atual e favorecem sua tendência a conservar-se
nele. Ele está em desordem quando as causas que o movem perturbam ou destroem a harmonia
ou o equilíbrio necessário à conservação de seu estado atual (p. 95).

Uma ideia inusitada pode ser inferida dessas citações: suponhamos que haja algum, por assim dizer, modus vivendi biológico que possa ser tido como qualitativamente ruim, de tal forma que a sua conservação, pela lógica, é um mal. Assim, a desordem seria um bem. A título de exemplo, um câncer institui uma forma de ordenamento biológico que, se conservado, produz malefícios. Assim, para combatê-lo, há de se instituir uma desordem bioquímica que perturbe a sua harmonia das células cancerígenas, o que, espera-se, produza benefícios.

\section{O conceito de natureza humana ampliada: princípios e efeitos}


Em compasso de continuidade com a seção anterior, nesta, prossigo defendendo uma visão materialista-biológica de humano. Agora, enfrento um conceito fundamental no debate filosófico, isto é, o de natureza humana. Minha proposta é ampliar radicalmente o que a constitui, recorrendo ao que os recentes avanços científicos têm permitido afirmar sobre o comportamento humano. Malgrado trivial, cabe registrar que não pretendo encerrar a rica polêmica em torno do conceito, mas sim apresentar argumentos que demonstram os benefícios teórico-conceituais da sua adoção da versão que proponho.

Conforme Stevenson e Haberman (1998), uma infinidade de coisas depende da concepção de natureza humana adotada. Buchanan (2001a), aproximando-se da problemática do artigo, afirma que o modo "como você pensa sobre a natureza vai moldar profundamente a sua atitude acerca do aperfeiçoamento biomédico em geral, mais especialmente os aperfeiçoamentos genéticos" (p. 26).

Sem dúvida, a importância da definição de natureza humana é crucial, pois "concepções diferentes de natureza humana conduzem a distintas ideias sobre o que devemos fazer e sobre como podemos fazer" (STEVENSON e HABERMAN, 1998, p. 4.) Stevenson e Haberman (1998), resumidamente, dividem os efeitos da definição de natureza humana em dois campos:

\footnotetext{
(...) para indivíduos, o significado e o propósito de nossa vida, o que devemos fazer ou nos esforçar para conseguir, o que podemos esperar alcançar ou nos tornar a ser; para as sociedades humanas, sobre qual visão de comunidade humana podemos investir e que tipo de mudanças sociais devemos fazer" (p. 3).
}

As divergências sobre a natureza humana se aplicam a distintos campos e parecem infindáveis. Para tentar recobrir a variedade confusa de questões envolvidas, dividi-las-ei em três grupos. No primeiro, que chamo de geral, estão perguntas como: há coisas inatas universalmente compartilhadas? Há uma essência imutável ou a única característica essencial é ser mutável e moldável pelo meio ambiente em que os humanos se inserem? Haveria algo que, a despeito do contexto, manter-se-ia, algo que resistiria às influências e mudanças; ou tudo varia de acordo com o meio e muda diacronicamente, e é isso que caracteriza a essência humana? Ou seja, o Homem, enquanto espécie, é essencialmente algo que não se modifica ou é natural e literalmente uma metamorfose ambulante? 
Em um segundo grupo, denominado de conteudista e diferencial, há questões como: o humano é identificado como tal por ser um animal com características mentais, emocionais e físicas específicas, distinguindo-se dos outros seres vivos? Tais características são identicamente compartilhadas? Homens e mulheres compartilham uma essência ou diferem-se em tantos aspectos que dificilmente poderíamos falar em mesma natureza? Aliás, os indivíduos, em geral, possuem as mesmas características ou cada um tem sua própria conformação, possuindo aquilo que é chamado de individualidade biológica, o que implicaria diferenças variadas? Ademais, dado indivíduo é um continuum existencial ou até mesmo um mesmo indivíduo varia ao longo do decurso da sua vida, de modo que seria incorreto referir-se à essência individual? Por fim, uma das mais relevantes, questiona-se se a essência humana é linear, convergente, 'boa' ou transitória, divergente e 'má'?

O terceiro grupo, intitulado de proveniência, resume-se, via de regra, ao dilema criacionismo ou evolucionismo, referindo-se às questões: o humano foi criado como é e de uma vez só e por Deus? Ou ele é fruto de um processo contínuo de adaptações evolutivas norteadas pela natureza?

O debate sobre o que o humano é se insere sobre esse pano de fundo. A natureza humana enfrenta questões semelhantes às dirigidas à natureza em geral. A reflexão sobre a natureza humana diz respeito às tentativas de definir quais as características fundamentais do humano, prever seus funcionamentos e comportamentos, bem como separá-los judicativamente. A reflexão sobre natureza humana também é comprometida por traços metafísicos (JAMES, 2002; FERN, 2004; PRESIDENT'S COUNCIL ON BIOETHICS, 2008). Aliás, um dos argumentos mais utilizados pelos que defendem a indisponibilização da natureza humana à instrumentalização e artificialização é o chamado playing of God ('brincado de Deus') (BUCHANAN, 2011a), como se vê, explicita ou implicitamente, em Kass (2002; 2003) e Sandel (2007).

Evidentemente, somente os que creem na existência de Deus e na sua ação determinante e privilegiada sobre a constituição humana podem aduzir e sustentar tal argumento. Se Deus existe e ele fez, preserva e direciona a 'coroa da sua criação', o humano, logo, ele teria direitos exclusivos sobre ela. Ou seja, se o humano intervier na sua 'natureza', ele estará usurpando funções divinas, argumento que impressiona os que compartilham alguma credulidade em Deus.

Todavia, será que há o mesmo efeito retórico sobre os incrédulos? Certamente, pela lógica, não. Afinal, se o firme fundamento de um argumento é a crença na existência e nas 
prerrogativas de uma entidade metafísica, se não se acredita nela, o argumento se torna inválido. Inobstante, sem considerar o fundamento do argumento, algo me parece explícito até mesmo para um crente em Deus: há muito, a nossa natureza é alvo de manipulação. Assim, ou bem brincamos de Deus faz muito tempo e este 'sacrilégio' se encontra indevida, mas amplamente legitimado; ou bem esse argumento não faz o mínimo sentido.

Nessa postura que contesto, predomina a visão de que a natureza é boa. Michael Sandel (2007), por exemplo, recorre à noção de Wisdom Nature ('sabedoria da natureza') para defender que devemos deixar a cargo da natureza a tarefa do aperfeiçoamento humano, pois ela já teria demonstrado sua capacidade no que tange à natureza em geral, o que já demonstrei ser questionável. Esse exemplo mostra que a crença em uma entidade supra-humana, com sabedoria e inteligência, permanece vigente e relativamente fortalecida entre nós, bem como é aduzida ao debate sobre o aperfeiçoamento humano.

Steven Pinker (2002) afirma que "todo mundo tem uma teoria da natureza humana" (p. 19). Ele sugere que isso tem a intenção de buscar prever o comportamento dos outros, por isso inventamos teorias que, supostamente, ajudam-nos a entender o que motiva as pessoas. Em suma, então, teorias sobre natureza humana pretendem dar conta da motivação e do comportamento humano.

Geralmente, as religiões partem de uma teoria da natureza humana e a discordância quanto a ela é um dos pontos de divergência, o que produz efeitos variados. Algo semelhante ocorre noutro campo do pensamento humano, a saber, a filosofia. Admitindo como amplamente conhecida a divergência entre filósofos modernos como Rousseau e Hobbes acerca da natureza humana, resta clara a vigência de uma perspectiva maniqueísta, do tipo 'ou ou', na tradição filosófica.

Conforme argumento, diferindo de uma concepção usualmente presente no debate, o conceito restrito ou dual de natureza humana precisa ser superado por um conceito que denominarei de natureza humana ampliada. Com a ampliação do que constitui a natureza humana, abre-se a possibilidade de considerá-la para além do bem e do mal ou de um conjunto conveniente e injustificadamente sumário de características que supostamente são boas, devendo ser promovidas, enquanto outras características são deixadas de fora, posto que fossem más, devendo ser combatidas. 
Dentre os prejuízos para o debate que uma acepção de natureza humana restrita traz, destaco: (1) o esquartejamento do humano, que leva à construção de uma entidade imaginária, constituída apenas por algumas partes eleitas, desconsiderando outros componentes que inclusive as determinam; (2) uma questionável ideia de normalidade, que está fundamentada nesse humano fíctício, criando um sem-número de anormalidades igualmente arbitrárias; (3) como resultado dos dois anteriores, uma aporética noção de ser humano, pois muitos indivíduos (crianças, doentes mentais graves, viciados, etc.) não se enquadram, embora sejam considerados humanos.

Proponho, em vez, uma noção ampliada de natureza humana, na qual um conjunto diversificado de caracteres - uns mais comuns, outros extremamente raros; uns mais desejáveis, outros extremamente indesejáveis - sejam incluídos, porque constituem a natureza complexa e, por vezes, contraditória, que a ciência tem mostrado ser manipulável. Com essa versão, presumo que haja ganhos teórico-conceituais preciosos: (1) a integralização do humano, considerando-o como um ser multifacetado e sobredeterminado; (2) a renovação e ampliação do conceito de normalidade, de tal forma que ele deixe de ser usado como modo de exclusão, negativação e legitimação de uma série de impropriedades praticadas contra os ditos anormais; (3) a desnaturalização e desneutralização dos nossos juízos de valor sobre o que deve ser promovido ou combatido na natureza humana, de modo que tenhamos que assumir a obrigação de justificar nossas opções, bem como a responsabilidade por elas.

Em resumo, o que defendo é que tudo que se manifesta no humano faz parte da sua natureza. As características físicas mais bizarras, os comportamentos mais nocivos, as deficiências e doenças mais incapacitantes são tão humanas quanto os fenótipos mais comuns, os comportamentos mais harmoniosos e aceitáveis, além da 'saúde' mais firme. O ponto fulcral é que preferimos certas características e funcionamentos que constituem dados ordenados do que outros, pois somos seres vivos que possuem a capacidade (limitada, mas existente) de optar pelo modo de vida que quer levar, inclusive modificando-se como um meio para se adequar e alcançar a um fim (bem-viver, boa sociedade, boa saúde, boas relações, etc.). Assim, investimos sobre o que desejamos e o que rejeitamos na nossa natureza complexa.

A promoção e o combate de traços da nossa natureza certamente é uma capacidade humana típica. Nenhum outro ser vivo conhecido é capaz disso. Destarte, talvez aquilo que nos constitua enquanto um ser vivo específico seja essa particularidade que pode ser denominada de cibernética, isto é, uma capacidade limitada, mas marcante e real de governar tudo que há 
(DUPUY, 2009), exercendo certo grau de controle até sobre si mesmo, sobre a nossa constituição necessária (nossas células, órgãos, disposições, tendências, etc.), através do cálculo dos efeitos e com vista a certos fins, buscando o que se quer ser.

Tal noção parece ser endossada pela ciência. Segundo Nicolelis (2011), natureza humana é o conjunto da enorme variedade de comportamentos especializados produzida pelo cérebro humano como um órgão formado por "imensas redes neuronais altamente conectadas e de operação extremamente dinâmica, conhecidas pela alcunha de circuitos neurais" (p. 18). Para o neurofisiologista de sistemas brasileiro, as redes neuronais microscópicas são as únicas responsáveis pela geração daquilo que caracteriza o humano. Cada pensamento, sentimento, ação, tendência, comportamento é uma tradução, um resultado do que ocorre no cérebro. Desde sempre, no humano, até mesmo as coisas antagônicas, provém desse órgão extraordinário, tudo,

(...) cada ato de pensamento, criação, destruição, descoberta, ocultação, comunicação, conquista, sedução, rendição, amor, ódio, felicidade, tristeza, solidariedade, egoísmo, introspecção e exultação jamais perpetrado por todo e qualquer um de nós, nossos ancestrais e progênie, ao longo de toda a existência da humanidade (NICOLELIS, 2011, p. 18-9).

Para decifrar os porquês da nossa natureza, da condição humana, portanto, é, desse ponto de vista, imprescindível “(...) decifrar os mecanismos fisiológicos que permitem salvas de eletricidade neurobiológica gestar e administrar o vasto (e antagônico) repertório de ações e comportamentos humanos" (NICOLELIS, 2011, p. 19; trecho entre parênteses incluído). Falar de natureza humana é, então, referir-se a algo biologicamente estruturado, especificamente associado a um determinado órgão, em que há multiplicidades de manifestações geralmente tidas como antagônicas.

Essa ideia de natureza humana dúbia (de tipo ' $e$ ') ou multifacetada pode ser encontrada, por analogia, embora sob os limites da época ${ }^{3}$, no pensamento de Holbach (2010). A partir do que chama de leis de atração e repulsão, ele sustenta que tal como o que os físicos afirmam sobre os corpos sólidos, "os homens, como todos os seres da natureza, estão submetidos a movimentos de atração e repulsão" (p. 78-9). Ainda segundo ele, "os moralistas designam essa disposição e os efeitos que ela produz sob o nome de amor ou de ódio, de amizade ou de aversão" (p. 78; grifos no original). 
Esse entendimento é um dos fundamentos do humanismo. Segundo Sloterdijk (2000), a crença do humanismo é que o humano é formado de tendências opostas. De um lado, estão as bestializadoras, desinibidoras ou embrutecedoras; do outro, as domesticadoras, inibidoras ou humanizadoras. Ambos os grupos de tendências fazem parte da nossa natureza. O ponto é que umas servem a certos propósitos majoritaria e costumeiramente do interesse da humanidade, enquanto outras os comprometem. Mas, se considerarmos períodos de conflito sangrento, por exemplo, talvez as tendências que interessem sejam outras. Assim, a partir de um juízo de fato (pragmático) e de valor (normativo), decide-se o que promover e o que combater. Contudo, repito, tudo é natureza humana, pois, em si, as características não são más nem boas, apenas são.

Cumpre salientar que um juízo com pretensões meramente constatativas (do tipo 'é assim que ocorre ou é') é acompanhado ou sucedido de um juízo de valor (do tipo é 'assim que deve ser'), sem que haja a preocupação de observar que os sentidos de bom e mau, desejável e reprovável e afins não são inerentes às coisas, mas concernentes às concepções de bem e de sociedade que são endossadas em dado momento e lugar. Essa omissão tem como resultado - e, talvez, até mesmo a intenção - a naturalização, um a priori, de algo que é arbitrado, a posteriori. Como uma típica falácia naturalista, isso precisa ser problematizado, pois a promoção de certas tendências ou características e o combate de outras podem ser resultantes de concepções moral ou politicamente insustentáveis, tirânicas, preconceituosas.

"Quem hoje se questiona sobre o futuro da humanidade e dos meios de humanização deseja essencialmente saber se subsiste alguma esperança de dominar as atuais tendências embrutecedoras entre os homens", diz-nos Sloterdijk (2000, p. 16). Assim sendo, o debate em torno do aperfeiçoamento humano passa, necessariamente, pela escolha do que deve ser promovido e o que deve ser combatido na natureza humana. E isso se dá, segundo a crença biotecnocientífica, pela manipulação da biologia humana.

Como vimos, a concepção de natureza humana de Nicolelis é completamente biológica. Mais especificamente, o cientista defende que ela está sediada em um órgão bem específico, o cérebro. Assim, Nicolelis esposa o que Ortega e Vidal (2007) definem como o sujeito cerebral, ou seja, "a figura antropológica que incorpora a idéia de que o ser humano e essencialmente reduzível a seu cérebro" (p. 257). Uma gama variada de fatores estaria enredada por uma espécie de neuralização da vida, o que gera a compreensão de que as neurociências têm um acesso privilegiado ao self, sendo capaz de explicar o humano como um todo, sua subjetividade, seus 
comportamentos, sua vida e morte (ZORZANELLI e ORTEGA, 2011). A importância devotada ao cérebro é tão grande que o tão propalado mapeamento do genoma humano chega a ser tido como secundário. Ortega e Vidal (2007) citam Alex Mauron, biólogo molecular e bioeticista norte-americano, que afirma que "se compararmos as explicações da personalidade e do comportamento 'baseadas em genoma' e 'baseadas no cérebro', o resultado é que os aspectos neurais da natureza humana são mais diretamente relevantes" (p. 258).

Obviamente, uma perspectiva que restrinja o humano às explicações biológicas e que invista em sua melhoria através de tecnociência certamente desperta bastante resistência por parte dos tecnofóbicos e transcentalistas, como é o caso de alguém como Leon Kass, proeminente bioeticista norte-americano, que presidiu, entre 2001-2005, o President's Council on Bioethics estadunidense, conhecido, e muito criticado também, por fundamentar seus argumentos tidos como bioconservadores em princípios religiosos, especificamente cristãos (AGAR, 2004; PINKER, 2008). Churchland (2011), por exemplo, afirma que "quando falamos da possibilidade de ligar em larga escala as perguntas sobre a nossa mente com a evolução nas neurociências, há aqueles que (...) nos advertem sobre os perigos do cientificismo" (p. 3).

Aquilo que Pinker chama de fervorosos impulsos religiosos não se aplica apenas a Kass. Em 2008, em um relatório do conselho supracitado, intitulado Human Dignity and Bioethics, outros pensadores se contrapuseram à ciência a partir da defesa de uma noção marcadamente metafísica de dignidade humana fundamentada numa perspectiva acrítica de que a religião tem um papel central na moralidade e na vida pública. Do seu ponto de vista, a natureza humana é deificação, aprioristicamente refletida à imagem e semelhança da divindade, o que a ciência profanaria, caso manipulasse, comprometendo a, por sinal, imprecisa ideia de dignidade humana.

Com a sua veemência e ironia peculiares, Pinker critica a ideia de alma humana defendida por gente como Kass, asseverando que "a suposta alma imaterial pode ser cortada com uma faca, alterada pela química, ligada e desligada pela eletricidade ou extinta por um golpe certeiro ou pela falta de oxigênio" (PINKER apud KASS, 2002, p. 137). Dado o ainda bastante relevante percentual daqueles que creem em Deus e na alma imaterial que sobrevive após a morte ${ }^{1}$, a ciência é, então, acusada de matar a alma, como sugere o título de um interessante debate realizado em 1999, mediado por Tim Radford, editor de ciência do jornal britânico The Guardian, envolvendo, além de Pinker, o famoso e polêmico biólogo evolucionista britânico Richard Dawkins². Em 2002, contra a crítica de Pinker e a 'arrogância' da ciência, Kass, 
ironicamente, diz que "dificilmente se sabe se impressiona mais a altura da arrogância de Pinker ou a profundidade de sua superficialidade. Mas ele fala com a autoridade da ciência e poucos são capazes e estão dispostos a disputar com ele em seu próprio terreno" (KASS, 2002, p. 137). Vemos apenas mais um capítulo da antiga e, talvez, insuperável polêmica ciência e conhecimento versus religião e fé.

No que concerne à questão alma versus cérebro, a insolubilidade da discordância se evidencia pelo fato de a ciência, ao menos até hoje, não poder falar nada sobre o pós-morte, o transcendental, o imaterial. Assim, ainda que aquilo tradicionalmente tido como a manifestação álmica ou espiritual seja radicalmente comprometido com aqueles exemplos de Pinker, é possível que a alma, senda separada do corpo físico, continue a existir fora deste mundo. $\mathrm{O}$ cérebro pode ser interpretado como o ponto de apoio transitório da alma, de modo que o seu comprometimento gere um retorno desta para algo como o 'mundo das almas'. Mas o ponto de cientistas como Pinker é que a alma é um termo ficcional para cérebro, o que cria um impasse insolúvel. Não existe alma, mas cérebro, diriam os cientistas. Porém, ante ao que acabo de argumentar, presumo que tal afirmação não possa ser comprovada empirica e cientificamente.

Mas, respeitando os limites mencionados, quero me posicionar para encerrar esta seção. É razoável afirmar que não há estado de espírito, mas sim estados neuroquímicos. O materialismo biológico que defendo superou os limites apontados por Ferry e Vincent (2011), na medida em que, à luz das recentes descobertas científicas, entende que na biologia está tanto a necessidade quanto as condições para o que denomina-se de liberdade. Sem endossar mais esse nebuloso conceito, concordo com Valenzuela (2005) quando ela diz que nos genes estão tanto a determinação quanto as condições de possibilidade do agir livre. A genética que determina a configuração cerebral humana é a mesma que nos capacita a nos modificar.

A ansiedade, afecção que não determinamos, pode ser controlada farmacologicamente. A inteligência e memória podem ser potencializadas por remédios. O autocontrole é um estado passageiro que pode ser comprado na farmácia. Ainda que permaneça controversa (FODDY e SAVULESCU, 2006; NEIL, 2006; FODDY e SAVULESCU, 2010), há elementos que sugerem que os chamados adictos possuem uma baixa capacidade de se controlar, o que geraria uma espécie de deficiência de autonomia. Sem endossar um conceito tão difícil de precisar como este, há relatos de que o uso de medicamentos torna a vida dos indivíduos tidos como adictos melhor ou mais controlada e socialmente harmoniosa, permitindo que ele exerça um nível maior de 
escolha sobre seus desejos. Sem considerar as controvérsias sobre a neurociência da ética, sentimentos tidos como morais, tal como a empatia, têm tido os seus mecanismos cerebrais desvendados pela neurociência, de modo que se torna possível falar em aperfeiçoamento moral (CHURCHLAND, 2011; NICOLELIS, 2011).

Por último, no campo da nova genética, conforme Buchanan et al. (2001), um conjunto de intervenções direta e indiretas já está disponível. A título de exemplo, quanto às diretas, cito a terapia genética, pela qual genes normais ou desejáveis são inseridos em células somáticas ou germinativas.

Evidentemente, tais 'melhorias' são relativas tanto às características selecionadas para serem promovidas quanto às concepções de bem e de sociedade adotadas, ratificando o que venho defendendo ao longo do texto. Contudo, enquanto elas vigerem, fará sentido denominar as intervenções que as promovem como aperfeiçoadoras.

Em suma, o conceito de natureza humana ampliada permite desnaturalizar a ideia de aperfeiçoamento humano, colocando-a sob total responsabilidade do arbítrio humano. Como o normal e o anormal, o bom e o mau, o desejável e o indesejável são criações humanas que se referem hermeneuticamente a uma natureza humana enquanto biologia que é profundamente manipulável, o bioaperfeiçoamento é uma tomada de decisão sobre que vida queremos promover, envolvendo um conjunto de ações que clamam por prudência e audácia, aposta e crítica.

\section{O futuro da humanidade sob o espectro do pós-humano: medo e esperança justificados?}

Para encerrar a presente reflexão, examino o que chamarei de falacioso eixo da polêmica entre pró-aperfeiçoamento e anti-aperfeiçoamento. O debate em torno do aperfeiçoamento humano está fortemente ancorado em um ponto que assombra a alguns e enche de esperança a outros: a pós-humanidade. Compartilho o entendimento de Cole-Turner (2011) de que póshumano é um conceito suficientemente amplo, impreciso e virtual para que possa determinar objetiva e claramente algo. Savulescu, por exemplo, define o pós-humano como "seres originalmente 'evoluídos' ou desenvolvidos a partir de seres humanos, mas significativamente diferentes, de tal modo que não são mais humanos em qualquer aspecto significativo" (p. 214). De acordo com Lecourt (2003), é um conceito inventado por engenheiros de informática estadunidenses em meados dos anos 1980 para categorizar seres como os cyborgs, clones, super- 
homens, inteligência artificial, etc. Wolfe (2010), citando Joel Garreau, usa uma definição bem similar a de Savulescu, já que afirma que pós-humanos são os seres cujas capacidades básicas excedem radicalmente às dos humanos.

Embora vago, o estágio pós-humano é a pedra angular do movimento transumanista. Transumanismo é um movimento histórico para o qual há muitas definições, as quais apresentam pontos de convergência e divergência. Segundo Wolfe (2010), ainda mencionando Garreau, ele é um movimento que se dedica ao aperfeiçoamento das capacidades intelectuais, físicas e emocionais do humano, crendo no engenharia evolutiva dos pós-humanos. Para Young (2006), ele é uma crença na superação das limitações humanas por meio da razão, da ciência e da tecnologia, apoiando as tentativas de eliminar doenças, de melhorar o corpo e a mente, e, no limite, superar até mesmo a morte. Ele acredita que assim "como o humanismo nos libertou das cadeias da superstição, o transumanismo nos livrará de nossas cadeias biológicas” (2006, p. 32). Já segundo More (1990), o transumanismo deve ser entendido como um processo perpétuo de superação dos limites do humano, com um emprego escrupuloso da razão, da ciência, da lógica e do pensamento crítico, tendo por base os seguintes princípios: expansão ilimitada, autotransformação, otimismo dinâmico, tecnologia inteligente, inteligência crescente, ordem espontânea, liberdade, prazer e longevidade. Isso leva à definição de Jotterand (2010), para o qual ele é um movimento ideológico fundamentado na filosofia Iluminista e humanista. Destarte, é plausível asseverar que os transumanistas defendem uma espécie de Iluminismo de cunho biológico, expropriando da natureza o monopólio da evolução, da mutação.

Por outro lado, a pós-humanidade é tida como uma pedra de tropeço. Fukuyama (2004), por exemplo, denunciou o transumanismo como uma das dez ideias mais perigosas do mundo. Ainda para o famoso cientista político norte-americano, sérias decisões políticas terão de ser tomadas no tocante ao futuro pós-humano, haja vista “(...) o potencial abismo moral que esse futuro abre diante de nós” (p. 17). Mas será que a esperança e o temor se justificam? À luz do conceito que proponho neste artigo, analiso brevemente esta questão, a fim de respondê-la negativamente.

É a mudança da natureza humana que é temida e desejada. Contudo, considerando que desde Darwin o Homem é considerado um ser vivo como outro qualquer, a mudança pode ser inevitável. Como ser vivo, o humano está submetido e é o resultado das leis naturais e dos processos que estas induzem ou estabelecem (RICHARDS, 2000). Assim, sob a perspectiva 
darwinista, que é tida como a mais plausível explicação científica existente, o humano é um ser evolutivo, em constante mutação, pois, do contrário, não faria sentido falar em evolução humana.

Sendo assim, é imperativo considerar que o humano vem mudando, já que, como ser biológico, respeita a regra evolutiva aplicada a todos os outros seres da natureza (MEYER e ELHANI, 2005; CHEDIAK, 2008). Com isso, não há alfa e ômega humanos, mas restam as formasHomem produzidas pelo choque das forças existentes em dado momento (DELEUZE, 2005). E, outrossim, fica cada vez mais claro que o homem é um inventor de si mesmo, um coparticipante da natureza no processo de sua constante mutação. Aliás, ratificando uma afirmação supracitada, essa é uma característica que tipifica a natureza humana, qual seja, a capacidade biológica de (re)inventar a própria vida, assumindo parcela do protagonismo no tocante à sua metamorfose. $\mathrm{O}$ humano é um demiurgo de si mesmo e pode estar próximo de criar formas-vida desde a sua origem.

Diante desses argumentos, que reconheço como prenhes de polêmicas, surpreende a tese bioconservadora de que precisamos preservar a natureza humana 'tal como ela é'. Afinal, em termos heraclitianos, se ela é algo, é constante devir biológico, e não algo fixo, imutável, completo. Fazendo justiça aos bioconservadores, eles não negam a mudança, mas a consideram, por assim dizer, um assunto da natureza. Como vimos, e como Agar (2004) também compreende, a preservação das prerrogativas da natureza deve ser compreendida num contexto histórico de uma tradição de pensamento encampada por pessoas que condenam qualquer forma de aperfeiçoamento não-natural, porque estaria usurpando as funções divinas. Para ele, tais pessoas alegam que foi Deus quem criou ('naturalmente') as mentes e corpos humanos, de tal modo que tentar recriá-los melhores laboratoriamente seria brincar de Deus, entendimento que pode ou deve ser revisto ante ao desenvolvimento do pensamento humano, das biociências.

Mas como tal perspectiva pode ser sustentada frente à história de manipulação terapêutica? É curiosa admissão de que devemos combater a natureza precária do humano em certos aspectos (doenças e deficiências), mas, concomitantemente, devemos preservá-la noutros (melhoria de capacidades para além do nível normal), como é o inusitado argumento defendido por Habermas (2000; 2004). Isto é, devemos tratar (terapia), mas não melhorar (aperfeiçoamento) o humano.

Todavia, se faz parte da natureza humana adoescer, como venho defendendo, contornar ou erradicar doenças, imunizar humanos, intervir para que deficiências não se concretizem não são 
um claro modo de inteferir na criação divina, na natureza? Ademais, seria irreal ou implausível considerar que as intervenções terapêuticas são formas de melhorar o humano, a sua vida? Penso que não, até porque há um claro discurso nesse sentido

Se alguns humanos vivem muito mais do que outros ou do que, em média, vivia-se antigamente; se a estatura média do humano foi sensivelmente alterada entre os séculos XIX e $\mathrm{XX}$; se alguns humanos vivem com órgãos de outras pessoas ou só sobrevivem porque lançam mão da interface humano-máquina (por exemplo, uso de marcapassos cardíacos), entre outras alterações ou efeitos biotecnocientíficos, o que diríamos deles, que são pós-humanos? Será que alguém ficaria estupefato, sem saber como lidar com essa 'nova espécie', ao saber que uma pessoa usa marcapasso, nasceu de uma fertilização in vitro, que utiliza fármacos que prometem estender o tempo da sua vida ou chips cravados em seu cérebro para controlar os tremores decorrentes do mal de Parkinson? Penso que não. Assim, considerando que o humano é naturalmente mutável e que sofre, há muito, um processo natural e artificial de alterações, infiro que, ao menos até aqui, é improvável que encontremos com um pós-humano pelas ruas.

Por fim, a tese pós-humana é refutável, pois a ideia de que humanidade pode ser transformada como um todo pela manipulação genética é contrafactível. Segundo Daniels (2009), a tese da pós-humanidade esbarra em um limite empírico, a saber, que a intervenção aperfeiçoadora em um indivíduo não produzirá um efeito de conjunto. Mesmo a evolução capitaneada pela natureza não foi capaz de homogeneizar todos os exemplares da espécie (MURPHY, 2012). Com isso, o temor ou a esperança de que uma nova espécie será criada geneticamente, em laboratório, merece ser revista criticamente, pois pode estar enviesando erroneamente o debate. Isto é, o futuro da humanidade pode permanecer mais incerto do que alguns gostariam e menos determinável do que alguns temem. 


\section{Notas}

${ }^{1}$ Pinker (2002) afirma que, de acordo com levantamentos recentes, 76\% dos norte-americanos acreditam em tais coisas.

${ }^{2}$ Disponível em: <http://www.edge.org/3rd_culture/dawkins_pinker/debate_p1.html>. Acesso em: 12 mar. 2010.

${ }^{3}$ A primeira edição data de 1771 . 


\section{Referências bibliográficas}

AGAR, Nicholas. Liberal Eugenics: In Defense of Human Enhancement. Oxford: Blackwell Publishing, 2004.

ALLHOFF, Frtiz et al. Ethics of Human Enhancement: 25 Questions \& Answers. Studies in Ethics, Law, and Technology, v. 4, issue 1, 2010.

BACKES, Marli T. S. et al. Noções de natureza e derivações para a saúde: uma incursão na literatura. Physis, v. 20, n. 3, p. 729-751, 2010.

BOSTROM, Nick. The Future of Humanity. In: OLSEN, J-K. et al. (eds.). New Waves in Philosophy of Technology. New York: Palagrave MacMillan, 2009.

. Transhumanist Values. Review of Contemporary Philosophy, v. 4, n. 1-2, p. 87-101, 2005.

BOSTROM, Nick and SANDBERG, Anders. The Wisdom of Nature: An Evolutionary Heuristic for Human Enhancement. In: SAVULESCU, J. and BOSTROM, N. (eds.). Human Enhancement. Oxford University Press, 2009, p. 375-416.

BUCHANAN, Allen. Better than Human. The Promise and Perils of Enhancing Ourselves. Oxford: Oxford University Press, $2011 \mathrm{a}$.

BUCHANAN, A. et al. From chance to choice. Genetics and justice. Cambridge: Cambridge University Press, 2001.

. Beyond Humanity? The Ethics of Biomedical Enhancement. Oxford: Oxford University Press, $2011 \mathrm{~b}$.

CHEDIAK, Karla. Filosofia da biologia. Rio de Janeiro: Jorge Zahar Ed., 2008.

COLE-TURNER, Ronald (ed.). Christian Hope in na Age of Technological Enhancement. Washington, D.C.: Georgetown University Press, 2011.

DANIELS, Norman. Can Anyone Really Be Talkink about Ethically Modifying Human Nature? In: SAVULESCU, J. and BOSTROM, N. (Orgs.). Human Enhancement. Oxford University Press, 2009, p. 25-42.

DELEUZE, Gilles. Sobre a morte do homem e o super-homem. In: . Foucault. São Paulo: Brasiliense, 2005, p. 132-142.

DIAS, Maria C. e VILAÇA, Murilo M. Metamorfoses do humano. Notas sobre o debate ético em torno da biotecnologia para o aperfeiçoamento humano.Ethic@, v. 9, n. 1, p. 29-42, 2010. 
DUPUY, Jean-Pierre. Fabricação do homem e natureza. In: NOVAES, A. (Org.). Mutações Ensaios sobre as novas configurações do mundo. Rio de Janeiro: Agir; São Paulo: Edições SESC SP, 2008, p. 25-44.

. O transumanismo e a absolescência do homem. In: NOVAES, A. (Org.). A condição humana: as aventuras do homem em tempos de mutações. São Paulo: SESC SP e Agir, 2009, p. 89-122.

FERN, Richard L. Nature, God and Humanity. Envisioning an Ethics of Nature. Cambridge: Cambridge University Press, 2004.

FERRY, Luc e VINCENT, Jean-Didier. O que é o ser humano? Sobre os princípios fundamentais da filosofia e da biologia. Petrópolis, RJ: Vozes, 2011.

FODDY, Bennett and SAVULESCU, Julian. A Liberal Account of Addction. Philosophy, Psychology, and Psychiatry, v. 17, n. 1, p. 1-22, 2010.

. Addiction and Autonomy: Can Addicted People Consent to the Prescription of Their Drug of Addiction?. Bioethics, v. 20, n. 1, p. 1-15, 2006.

FUKUYAMA, Francis. Our Posthuman Future: Consequences of the Biotechnology Revolution. New York: Farrar, Straus and Giroux, 2002.

. Transhumanism: The World's Most Dangerous Idea?. Foreign Policy (144), p. 42-43, September 1, 2004. Retrieved November 11, 2011.

HABERMAS, Jürgen. Aclaraciones a la ética del discurso. Madrid, Trotta, 2000.

. O futuro da natureza humana: a caminho de uma eugenia liberal?. São Paulo, Martins Fontes, 2004.

HOLBACH, Barão de. Sistema da natureza ou Das leis do mundo físico e do mundo moral. São Paulo: Martins Fontes, 2010.

JAMES, William. Varieties of Religious Experience. A Study in Human Nature. New York: Routledge, 2002.

JOTTERAND, Fabrice. At the Roots of Transhumanism: From the Enlightenment to a PostHuman Future. Journal of Medicine and Philosophy, v. 35, n. 6, p. 617-621, 2010.

KANT, Immanuel. Ideia de uma história universal de um ponto de vista cosmopolita. São Paulo: Martins Fontes, 2010.

KASS, Leon R. (ed.). Beyond Therapy: Biotechnology and the Pursuit of Happiness. New York: Harper Collins, 2003. 
. Life, liberty and the Defense of Dignity. San Francisco: Encounter Books, 2002.

LECOURT, Dominique. Humain, posthumain. La technique et la vie. Paris: PUF, 2003.

MCKIBBEN, Bill. The End of Nature. London: Bloombury, 2003.

MERLEAU-PONTY, Maurice. A natureza. São Paulo: Martins Fontes, 2006.

MORE, Max. Transhumanism - Toward a Futurist Philosophy. 1990. Disponível em: < http://www.maxmore.com/transhum.htm>. Acesso em: 15 jan. 2011.

MURPHY, Timothy F. The Ethics of Impossible and Possible Changes to Human Nature. Bioethics, v. 26, n. 4, p. 191-197, 2012.

NEIL, Levy. Addicion, Autonomy and Ego-Depletion: A Response to Bennett Foddy and Julian Savulescu. Bioethics, v. 20, n. 1, p. 16-20, 2006.

NICOLELIS, Miguel. Muito além do nosso eu: a nova neurociência que une cérebros e maquinas - e como ela pode mudar nossas vidas. São Paulo: Companhia das Letras, 2011.

ORTEGA, Francisco e VIDAL, Fernando. Mapeamento do sujeito cerebral na cultura contemporânea. RECIIS, v. 1, n. 2, p. 257-261, 2007.

PINKER, Steven. The Blank Slate: The Modern Denial of Human Nature. New York: Viking Penguin, 2002.

. The Stupidity of Dignity: Conservative bioethics' latest, most dangerous ploy. The New Republic, Wednesday, May 28, 2008. Disponível em: <http://www.tnr.com/article/the-stupiditydignity>. Acesso em: 20 jan. 2010.

PRESIDENT'S COUNCIL ON BIOETHICS. Human Dignity and Bioethics. Washington, D.C., March, 2005.2 Disponível em: $<$ http://bioethics.georgetown.edu/pcbe/reports/human_dignity/human_dignity_and_bioethics.pdf >. Acesso em: 29 jan. 2010.

RABINOW, Paul and BENNETT, Gaymon. Designing Human Practices: An Experiment with Synthetic Biology. Chicago: University of Chicago Press, 2012.

RICHARDS, Janet R. Human Nature after Darwin. A Philosophical Introduction. New York: Routledge, 2000.

SANDEL, M. The Case Against Perfection: Ethics in the Age of Genetic Engineering. Cambridge, MA: Harvard University Press, 2007.

SMITH, Adam. Teoria dos sentimentos morais. São Paulo: Martins Fontes: 2002. 
STEVENSON, Leslie F. e HABERMAN, David L. Ten Theories of Human Nature. New York: Oxford University Presse, 1998.

VALENZUELA, Juliana G. Genoma humano y dignidad humana. Barcelona: Anthropos Editorial, 2005.

VILAÇA, Murilo e PALMA, Alexandre. A nova genética para além da gestão de riscos e promoção da saúde: prolegômenos ao conceito de Biodesign. Physis, v. 5, n. 3, p. 813-832, 2011.

WOLFE, Cary. What is Posthumanism? Minneapolis: University of Minnesota Press, 2010.

YOUNG, Simon. Designer Evolution: A Transhumanist Manifesto. New York: Prometheus Books, 2006.

ZORZANELLI, Rafaela e ORTEGA, Francisco. Cultura somática, neurociências e subjetividade contemporânea. Psicologia \& Sociedade, v. 23, p. 30-36, 2011. 